\title{
Invasive species and the Global Strategy for Plant Conservation: how close has Brazil come to achieving Target 10?
}

\author{
Michele de Sá Dechoum ${ }^{1,3^{*}}$, Alexandre Bonesso Sampaio ${ }^{2}$, Sílvia Renate Ziller ${ }^{3}$ \& Rafael Dudeque Zenni ${ }^{4}$
}

\begin{abstract}
Target 10 of the Global Strategy for Plant Conservation establishes that "Effective management plans are in place to prevent new biological invasions and to manage important areas for plant diversity that are invaded" by 2020 . The rationale for the target is that invasive alien species are a major threat to native plants, and thus should be excluded from areas reserved for the conservation of plant species, especially when endemic and/or threatened. In Brazil, although most management plans report the presence of invasive alien species and the need for management in federal protected areas, there are only a very limited number of management plans implemented. The national strategy on invasive alien species, published as CONABIO Resolution 05/2009, has not been implemented, so progress on policies and legislation focused on invasive alien species at the federal level has been slow. In order to reach an effective development of public policies in Brazil, federal environmental agencies must function as focal points and be in charge of coordinating actions aimed at (1) identifying priority areas for preventing and managing biological invasions, and (2) managing invasive alien species and reduce their impacts.
\end{abstract}

Keywords: biological invasion, control, invasive non-native plants, management, protected area.

\section{Resumo}

Na meta 10 da Estratégia Global para a Conservação de Plantas está estabelecido que, até 2020, planos de manejo efetivos serão implementados para impedir novas invasões biológicas e para manejar áreas importantes para a diversidade de plantas e que estejam invadidas. A justificativa para a meta é que espécies exóticas invasoras usualmente são uma grande ameaça de extinção a plantas nativas, e assim devem ser excluídas de áreas que são destinadas à conservação de espécies vegetais, especialmente aquelas que são endêmicas e/ou estejam ameaçadas de extinção. No Brasil, apesar da maior parte dos planos de manejo de unidades de conservação federais reportarem a presença de espécies exóticas invasoras nessas áreas, um número bem limitado de planos já foi implementado. A Resolução CONABIO 05/2009, que estabelece uma estratégia nacional sobre espécies exóticas invasoras, não foi colocada em prática, sendo lentos os avanços em políticas e legislação focadas em espécies exóticas invasoras em nível federal. Para que políticas efetivas sejam desenvolvidas no Brasil, órgãos federais da área ambiental devem funcionar como pontos focais e coordenar ações para (1) identificar áreas prioritárias para a prevenção e o manejo de invasões biológicas, e (2) para manejar espécies exóticas invasoras, reduzindo impactos pelas mesmas provocados.

Palavras-chave: invasão biológica, controle, exóticas invasoras, manejo, plantas unidade de conservação.

\section{Introduction}

Earth is currently undergoing its sixth mass extinction largely owing to human disruption of natural processes and ecosystems (Vitousek et al. 1997). Habitat transformation, especially due to deforestation, agricultural expansion and urbanization; overexploitation of resources; and pollution are among the main drivers of contemporary extinction events (Millenium Ecosystem Assessment 2005; Vitousek et al. 1997). Today's drivers of extinction are often multiple as they may occur together, and their negative

\footnotetext{
${ }^{1}$ Universidade Federal de Santa Catarina, Programa de Pós-graduação em Biologia de Fungos, Algas e Plantas, C.P. 476, Campus Universitário Trindade, 88040-900, Florianópolis, SC, Brasil.

${ }^{2}$ Instituto Chico Mendes de Conservação da Biodiversidade - ICMBio, Centro Nacional de Avaliação da Biodiversidade e de Pesquisa e Conservação do Cerrado, EQSW 103/104, bl. "C", Complexo Administrativo - Setor Sudoeste, 70670-350, Brasília, DF, Brasil.

${ }^{3}$ Instituto Hórus de Desenvolvimento e Conservação Ambiental, AC Baía Sul, C.P. 4543, 88047-971, Florianópolis, SC, Brasil.

${ }^{4}$ Universidade Federal de Lavras, Setor de Ecologia, Depto. Biologia, Campus Universitário, 37200-000, Lavras, MG, Brasil.

*Corresponding author: mdechoum@gmail.com
} 
effects can be synergic, causing unprecedented consequences to biological diversity. Albeit global, the impacts of human expansion are more intense in the tropics, where much of Earth's biological diversity is sustained (Laurance et al. 2014). For instance, the Brazilian Cerrado has lost 46\% (88 million ha) of native vegetation cover mostly due to agricultural expansion (Strassburg et al. 2017), and the Amazon biome has been reduced by 67.3 million ha (Nogueira et al. 2017) to give way to anthropic areas. While anthropic habitats and landscapes are not deprived of life and do sustain some level of biological diversity (Laurance et al. 2014), the intensive management nature of these areas tends to favor some types of species over others. Generalist, fast-growing, and prolific species ( $\mathrm{r}$-strategist), for instance, tend to be favored in constantly disturbed habitats in comparison to specialist species (K-strategist). Many invasive alien species (IAS) tend to be r-strategists (van Kleunen et al. 2010). Consequently, the conversion of natural ecosystems into anthropic systems benefits invasive species and create opportunities for biological invasions.

One of the most prominent impacts of biological invasions is the homogenization of the biota on Earth. Invasions of natural habitats by alien species are one side of biotic homogenization, whereas extinctions of native and endemic species are the other one (Olden 2006; Rosenblad \& Sax 2016). Through invasions and extinctions, biotic homogenization increases the similarity of biotas of different regions of the planet and decreases the world total biodiversity (Olden 2006). Virtually all ecosystems now have thriving alien species among its communities (van Kleunen et al. 2015). So much so that some regions of the planet now host more alien species than native species (van Kleunen et al. 2015; Dawson et al. 2017).

One of the main strategies adopted by countries to conserve their biodiversity is the establishment and maintenance of protected areas (e.g., national and state parks, biological reserves, and other wilderness areas). Many protected areas are designed to protect biodiversity by providing refugia to native species from the spread of invasive alien species (Gallardo et al. 2017). Thus, alien species occurring in these areas must be controlled and/or excluded. These actions are necessary given the chance that certain alien species will become invasive and cause negative ecological impacts, and that some alien species can have negative effects on ecological processes even when they become invasive (Wardle et al. 2011; Simberloff et al. 2012). Among the known impacts invasive alien plants have on native communities and ecosystems are reduction in native plant diversity, plant fitness, native animal abundance, increase in soil microbial activity, and increases in soil nutrient levels (Vilà et al. 2011; Pyšek et al. 2012).

In order to prevent and reduce the impacts of biological invasions on biological diversity, country governments which are signatories of the Convention on Biological Diversity (CBD) compromised to prevent the introduction of, control or eradicate those alien species which threaten ecosystems, habitats or species (CBD 2006 - Article 8h). Aiming at fulfill that commitment, several recommendations and requests are stated in $\mathrm{CBD}$ decisions. One of them requests countries to adhere to the Global Strategy for Plant Conservation (GSPC) that includes outcome-oriented global targets. This decision was originally set for the year 2010, and then renewed for $2020(<\mathrm{https}: / /$ www.cbd.int/gspc/strategy.shtml>, last accessed on 6 November, 2017). Target 10 of the GSPC for 2020 calls for "Effective management plans in place to prevent new biological invasions and to manage important areas for plant diversity that are invaded." The rationale is that invasive alien plants are one of the major causes of extinction of native plants and must therefore be excluded from areas established for the conservation of native species, especially those which are endemic or endangered.

Invasive alien species have been linked to recent extinctions of different taxa and are currently considered a major threat for the conservation of native flora and fauna (Bellard et al. 2016; Spatz et al. 2017). Invasions by alien species are the fourth major cause of plant extinction, being associated with almost $30 \%$ of the total number of species that are categorized as extinct in the IUCN Red List (Bellard et al. 2016). Most plant extinctions were caused by herbivores such as goats (Capra hircus), sheep (Ovis aries) and European rabbits (Oryctolagus cuniculus), and alien plant invasions (Bellard et al. 2016). However, impacts of invasive alien plants on the extinction rates of native plants may have been underestimated for lack of consideration of changes caused by introduced plants on landscape structure that can compromise native plant persistence on the longterm (Gilbert \& Levine 2013). As a consequence, deterministic extinction trajectories of native plants might be masked by short periods of time since invasion in different parts of the world, blurring our 
comprehension of the full impact of plant invasions on native biodiversity (Gilbert \& Levine 2013).

Many studies addressing the impacts of IAS on natural ecosystems are focused on highly relevant areas for biological diversity such as tropical islands and protected areas (Blackburn et al. 2004; Foxcroft et al. 2013; Doherty et al. 2016; Spatz et al. 2017). Biological invasions are the primary driver of vertebrate extinctions on islands (Blackburn et al. 2004; Doherty et al. 2016; Spatz et al. 2017), with catastrophic ecological consequences for entire ecosystems. For instance, the loss of island-inbreeding sea birds due to introduced predators can change plant and microbial ecological communities (Fukami et al. 2006), and the population decline of specialized pollinators limited the reproduction of endangered plant species in Hawaii (Aslan et al. 2013). In protected areas, some intentional introductions generate well known examples of impacts to the local flora. Invasive Schinus terebinthifolius has replaced native vegetation with monospecific stands in the Everglades National Park, Florida (Li \& Norland 2001), and Morella faya has displaced the endemic Metrosideros polymorpha over large areas in Hawaii Volcanoes National Park (Loope et al. 2014).

For the 2010 goal, Brazil aimed at implementing management plans for at least 100 IAS that threaten plants, communities or habitats and associated ecosystems. To our knowledge, in 2010 there were no management plans for alien plants implemented by the federal government. There were exceptions at the state level. In Rio Grande do Sul, the State Law 13.187/2009 established a program to control the invasive alien grass Eragrostis plana. In 2005, the Paraná state environmental agency (Instituto Ambiental do Paraná) started to manage and remove invasive alien plants from state protected areas (Zenni et al. 2016).

The new Brazilian target for 2020 is to have effective management plans in place to prevent new biological invasions and to manage important areas for plant diversity that are invaded. According to a 2011 IUCN bulletin (IUCN 2011), the 2020 target is "a combination of prevention and management inside critical areas and a first step towards the development of management plans for all types of important biological invasions that threaten plants, plant communities and associated habitats and ecosystems. Invasive species may be plants, animals, or microorganisms, and management plans should be developed to rectify the damage caused to plants and/or their communities and to restore ecosystem functions and services."

Brazil did not have an appropriate legal framework in 2010 to achieve Target 10 of the GSPC, and still has not (for details, see text below and Zenni et al. 2016). However, between 2010 and 2020, some initiatives were set in motion, especially the design of National Action Plans for threatened species which often include actions against invasive alien species, indirectly covering Target 10 (ICMBio 2017). In order to quantify and understand if actions linked to GSPC Target 10 were being carried out in Brazil, we reviewed the most recent management plans of federal protected areas.

\section{Methods}

We systematically reviewed all management plans of protected areas available in the ICMBio (Brazilian Institute for Biodiversity Conservation - Instituto Chico Mendes de Conservação da Biodiversidade, in Portuguese) website $(<\mathrm{http}: / /$ www.icmbio.gov.br/portal/planosmanejo $>$ ) in July, 2017. For each of the management plans, we recorded (a) if invasive alien species were known to occur in the area, (b) if any management action was indicated for the area, and (c) which management action was indicated. We assessed protected areas registered in the National System of Protected Areas (Sistema Nacional de Unidades de Conservação, in Portuguese - Federal Law 9985/2000) because of the lack of a clear definition of which, exactly, are "important areas for plant diversity" referred to in the GSPC target.

Parallelly to the revision management plans, we sent a questionnaire to managers of 313 federal protected areas in Brazil and 13 ICMBio Research Centers (Appendix 1, freely available on the following link: $<$ https:/figshare. com/s/e935c7901996848da105>, DOI: 10.6084/ m9.figshare.5975425). We asked questions related to the occurrence of invasive alien plants in protected areas and their impacts: location of invasive plants, size of the area of occurrence, potential impacts on biodiversity, history of introduction, control actions taken and suggested, and source of the information provided.

\section{Results}

Out of the 324 federal protected areas, we found 248 management plans available on the ICMBio website. Eight plans were either not publically available or the files were corrupted. 
For the remaining 240 protected areas, $43 \mathrm{did}$ not mention invasions or invasive species. In the remaining 197 management plans (82\%), the presence of invasive species inside the protected area was reported and some course of action was indicated for invasive species and/or invasions. Some management plans suggested more than one course of action. The most frequent recommendation was eradication $(\mathrm{n}=111)$, followed by control $(\mathrm{n}=90)$, research $(\mathrm{n}=84)$, restoration $(n=49)$, prohibition $(n=47)$, monitoring $(n=43)$, management $(n=40)$, confinement $(n=31)$, border inspection $(\mathrm{n}=17)$, and replacement $(\mathrm{n}=16)$ (Fig. 1). Indications for courses of action towards invasive species, however, were only vaguely cited and none of the management plans presented a detailed action plan including goals, timelines, budget, tasks, or task assignments.
Out of the 313 questionnaires sent out, we only received answers from managers of 15 protected areas, which summed up to 145 occurrences for 84 alien plant species. In the majority of the questionnaires (94\%), answered questions $(52 \%)$ were related only to species occurrences. Invasive alien species were registered occurring in natural habitats in $56 \%$ of the cases/ occurrences, and in disturbed areas in $20 \%$ of the cases; the remaining records did not specify which habitats were invaded. The invaded area was larger than one hectare in $35 \%$ of the cases, with $18 \%$ of the occurrences registered in more than five independent areas inside the protected area. Alien species were said to be at least naturalized (i.e., forming self-sustaining populations) in the protected area by $50 \%$ of the respondents, and the history of introduction in each protected area

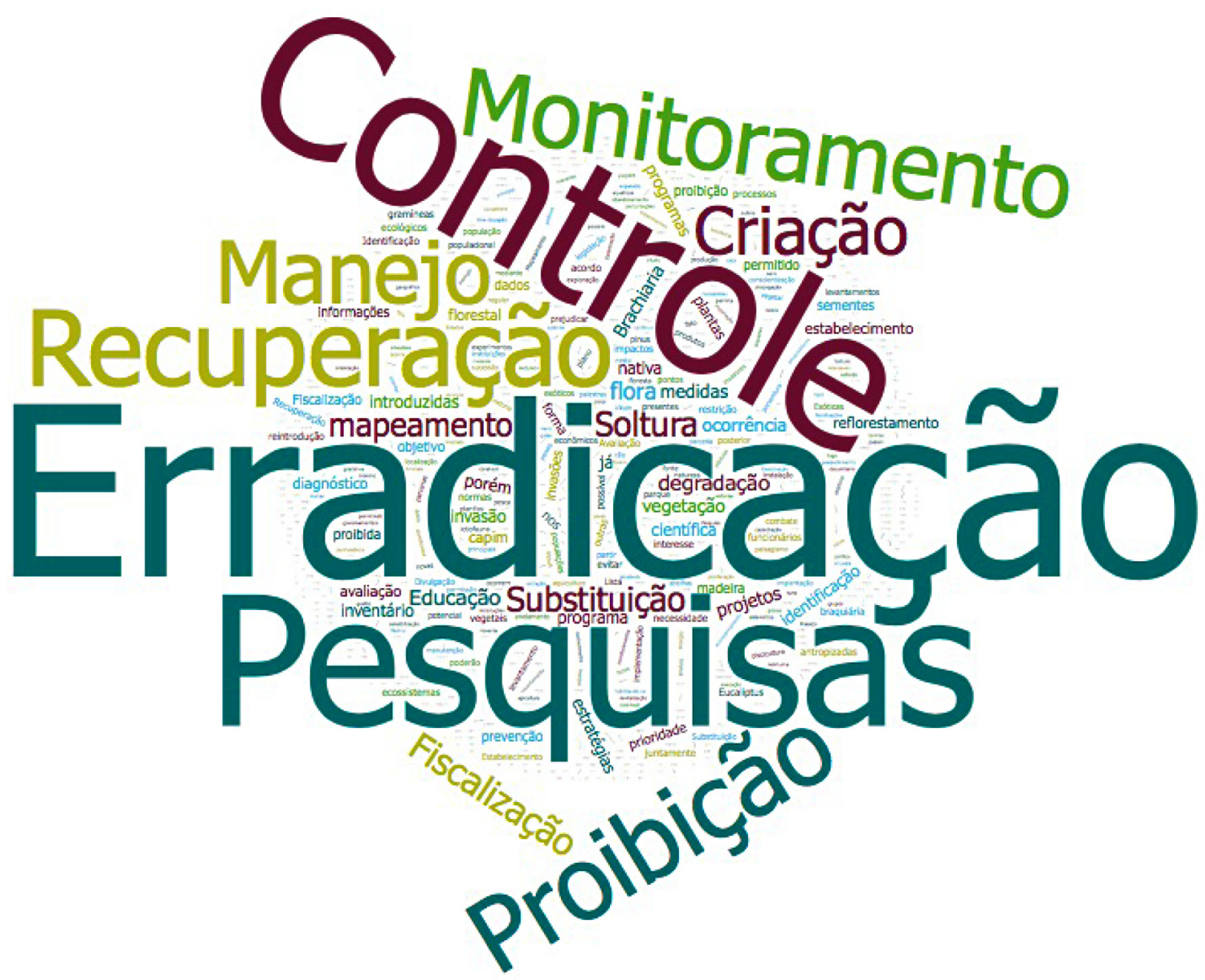

Figure 1 - Word cloud of the most frequently terms used as recommendations for invasive alien species and biological invasions in Brazilian federal protected areas. Recommendations were extracted from the management plans developed for 248 protected areas. Larger font sizes indicate recommendations more frequently made. 
was known for only $46 \%$ of the species. Thirtytwo percent of the species were considered to be causing significant negative impacts to biodiversity, whereas $16 \%$ of them were considered to harm threatened species. Only 19\% of the respondents described existing control actions, and 16\% pointed out suggestions for management. Only $47 \%$ of the information about management was linked to a source (i.e., bibliography or personal communication).

The respondents showed some confusion regarding the species identification and the correct categorization of alien species as invasive. Fifteen percent of the cited species were identified at the genus level and two species were identified by their vernacular names. While the questionnaire was explicitly about invasive alien species, cultivated non-invasive alien species were also cited, such as: Carica papaya (papaya), Manihot esculenta (manihot), Musa paradisiaca (banana), Pyrus communis (pear), Prunus persica (peach), and Zea mays (corn). The most frequently cited invasive alien species in the questionnaires, with occurrences registered in five of the 15 protected areas were: Urochloa decumbens, Impatiens walleriana, Psidium guajava and Pinus sp. At the Saint-Hilaire/ Lange Wildlife Refuge (Refúgio da Vida Silvestre Saint Hilaire/Lange), the impact of Urochloa decumbens and Impatiens walleriana on the habitat of the threatened bird Stymphalornis acutirostris (Reinert \& Bornschein 2008) was the most consistent impact described in the questionnaires.

The revision of management plans and questionnaires seems to indicate that protected areas are far from having effective management plans in place to prevent new biological invasions and to manage important areas for plant diversity that are invaded. Although some adequate initiatives might exist, the general rule for protected areas seems to be the absence of adequate training and practical action. For animals, a recent review indicated that $87 \%(\mathrm{n}=101)$ of the protected areas with invasive alien animal species had management recommendations in the management plan; $79 \%(n=81)$ of these had some control measures implemented (Guimarães \& Schmidt 2017). However, the authors considered that most of the recommendations were generic, and none of the plans had specific IAS control programs (Guimarães $\&$ Schmidt 2017). For both animals and plants, we see a similar pattern: generic guidelines for invasive alien species, low level of knowledge and training, and a small number of control actions in place.

\section{Discussion}

Global and national responses

to Target 10 of GSPC

A mid-term review of progress towards the Global Strategy for Plant Conservation (GSPC) was carried out in 2014. The review was published by the CBD Secretariat in collaboration with Botanic Gardens Conservation International (BGCI) as CBD Technical Series No 81 (Sharrock et al. 2014). According to this review, the evidence suggests that progress was insufficient to meet the target in nearly all countries, although some encouraging activities were on-going in managing areas already affected by biodiversity loss.

An important global result was the establishment of the International Plant Sentinel Network (IPSN) in order to facilitate collaboration between botanic gardens and arboreta, National Plant Protection Organizations (NPPOs) and plant health scientists. They are meant to provide botanic garden professionals with training and diagnostic support to better monitor and protect their collections; facilitate greater collaboration about invasive pests and pathogens among botanic gardens and with other organizations with improved databases and communication protocols; and enhance garden outreach efforts to educate their communities on the impact of high-consequence plant pests and pathogens and engage individuals as "First Detectors". The IPSN currently includes 41 botanicals gardens in 18 countries $(<\mathrm{http}: / /$ www.plantsentinel.org/the-network/>). None of the Brazilian botanic gardens participate in the initiative, but no country in the Americas is part of the initiative. On the other hand, the GSPC targets related to botanical garden collections are being thoroughly developed and are expected to be achieved by 2020 (Forzza et al. 2016).

In South Africa, the National Strategy for Plant Conservation (NSPC) was developed under the leadership of the South African Biodiversity Institute (SANBI), with support from the Botanical Society of South Africa and the collaboration of botanists from conservation agencies, non-governmental organizations and academic institutions. The NSPC includes 16 outcome-oriented targets, which are aligned with the outcomes and activities of the National Biodiversity Strategy and Action Plan (NBSAP) (South Africa's Strategy for Plant Conservation 2015). In 2008 an Invasive Species Program was established at the SANBI, funded by the 
Working for Water Programme, to specifically engage in the early detection of new invasive alien species, conduct risk assessments for postborder introductions and work on the eradication of invasive alien species that have just started to spread (SANBI 2008). In accordance with the NSPC, this program is actively monitoring 42 emerging invasive species (those that still have limited distribution), conducting research to understand the process of legal introductions and developing policy interventions to prevent them, conducting risk assessment for 174 plant species, and producing management plans for species requiring compulsory control to ensure eradication within a specified timeframe.

The Great Britain (GB) Invasive Non-Native Species Framework Strategy was published in 2008 and reviewed in 2013, with recommendations to advance the strategy published in 2014 (GBNNSS 2015). The Strategy focuses on preventative measures and on preventing the establishment of new invasive species by 'horizon scanning' to identify emerging threats. "Horizon scanning is a systematic examination of information to identify potential threats, risks, emerging issues and opportunities allowing for better preparedness and the incorporation of mitigation and exploitation into the policy making process" (GBNNSS 2015). Plantlife and the Freshwater Biological Association have undertaken horizon scanning for 599 alien freshwater and terrestrial plants. In the assessment, 92 plants were ranked as 'critical', requiring a full detailed risk assessment as a matter of priority. Other 55 species were ranked as 'urgent', for which a full risk assessment was recommended. Following detailed risk assessment of individual species, a key part of the GB Strategy is the production of Invasive Species Actions Plans (ISAP). These plans have been produced for water primrose (Ludwigia grandiflora) and a further four are in development. In addition, five invasive aquatic species are banned from sale in England since April 2014. The Invasive Alien Species Regulation was implemented in January 2015 with a list of invasive alien species being agreed to in 2016 .

Public policies, strategies

and action plans in Brazil

In 2001 the Ministry of Environment, EMBRAPA (the Brazilian Agricultural Research Agency) and the Global Invasive Species Programme (GISP) organized a meeting for representatives of South American countries in
Brasilia with the intention of forging international cooperation on invasive alien species prevention and management (Ziller et al. 2005). In 2004, the Ministry of Environment issued a call for proposals for the first national inventory of invasive alien species in terrestrial, freshwater and marine habitats as well as species that impact health and production systems. The inventory was funded by a GEF (Global Environment Fund) project entitled "Conservation and sustainable use of Brazilian biodiversity - Probio". The compilation of data led the Ministry of Environment and partner institutions to organize the first National Symposium on Invasive Alien Species, held in Brasilia in December 2005. The symposium was a national milestone for invasive alien species, as a significant increase in technical, legal and scientific references has been observed since then (Zenni et al. 2016).

In August 2006, CONABIO Deliberation 49 established a permanent working group for invasive alien species issues, which included representatives from several Ministries and other institutions. The working group developed a national strategy for invasive alien species that was published in 2009 as CONABIO Resolution No. 9. Once the National Strategy was promulgated, the working group stopped meeting and the strategy was not implemented, and is currently under review to include an objective action plan, to be completed in 2018.

Also in 2009, the Ministry of Environment published a report on invasive alien marine species (Lopes 2009), as a result of the surveys conducted between 2004 and 2005. Only in 2016 the report on invasive alien freshwater species was published (Latini 2016). The report on terrestrial species has not been published to date.

In 2014, the National Program for the Conservation of Species Threatened with Extinction (called Pro-Species for short) was instituted by the Ministry of Environment. A new proposal was developed for the GEF to address the goals of this program, and granted approval in 2016. This project includes actions against the main threats to biological diversity, including a component on invasive alien species. Implementation should start in 2018 and address some of the concerns described in this article.

In 2016, the Ministry of Environment started working on National Action Plans for three invasive alien species of national concern: the wild boar (Sus scrofa), the golden mussel (Limnoperma fortunei) and sun corals (Tubastraea spp.). The Wild Boar 
National Action Plan was formally approved in 2017 through joint regulations of the Ministry of Environment (Ministério do Meio Ambiente, in Portuguese) and the Ministry of Agriculture, Livestock and Supply (Ministério da Agricultura, Pecuária e Abastecimento, in Portuguese) (Portaria InterMinisterial 232/2017). The other plans are expected to be completed in 2018. As these plans are directed at animal species, two of which are aquatic, they do not effectively contribute with the achievement of Target 10 .

A complementary effort led by the Ministry of Environment since 2004 is the development of national action plans for species threatened with extinction. Given the role IAS play as a threat to endangered species, many of the plans include control actions. The National Action Plan for the conservation of the endemic flora of Rio de Janeiro threatened with extinction includes actions to support the implementation of a State Program for Invasive Alien Species, with capacity building, replacement of invasive ornamental plants in cities and restoration efforts (Pougy et al. 2017).

The agencies IBAMA (Instituto Brasileiro do Meio Ambiente e de Recursos Naturais Renováveis, in Portuguese; Brazilian Institute for the Environment and Renewable Natural Resources) and ICMBio work closely with the Ministry of Environment. IBAMA is responsible for controlling the introduction of alien invasive species that may threaten ecosystems, habitats or native species (Complementary Federal Law 140/2011), as well as regulating species imports. The agency is also in charge of issuing regulations on breeding and use of non-native animal species and biological control agents. From 2017, the Department for the Sustainable Use of Biodiversity and Forests (DBFLO) is attributed with the coordination, supervision, proposal of regulations and measures and with implementing control actions for invasive alien species through the Coordination for Management, Destination and Management of Biodiversity (COBIO). The new responsibilities of the Department also include the proposition of criteria and measures for the prevention, early detection, risk assessment, assessment of pathways and vectors of spread of invasive alien species, as well as the issue of permits for invasive alien species management throughout the country (Portaria IBAMA 14/2017).

ICMBio is responsible for national protected areas. Although the presence of many invasive alien species in many protected areas throughout the country has been widely recorded (Sampaio \& Schmidt 2013; Ziller \& Dechoum 2013; Guimarães \& Schmidt 2017), ICMBio does not have a department in charge of practical management. Practical actions therefore are difficult to implement even by those willing to act due to the current institutional framework of the organization.

At the state level, progress has been made in the south of Brazil where the states of Paraná, Santa Catarina and Rio Grande do Sul published official lists of invasive alien species and complementary regulations. Control actions are in place in many state protected areas, and state committees managing state programs on invasive alien species have been established in Paraná and Santa Catarina.

Recommendations for a post-2020 Target

Achievement of targets related to biological invasions for the conservation of biodiversity must begin with the implementation of the Brazilian National Strategy for Invasive Alien Species. Secondly, Brazil national focal points, focal institutions or a working group of organizations must be established and acknowledged to take charge of linking existing actions and programs and create demands specifically related to the target. Currently, all the work on biological invasions in Brazil is done independently by several groups without a coordinated agenda (Zenni et al. 2016). The Ministry of Environment, along with IBAMA and ICMBio, have formed a working group with focal points of each institution to oversee the development of national action plans for three invasive species of national significance, review the national strategy and develop a proposal for the GEF focused on threatened species and causes of threat, which include invasive alien species.

A fund must be established in order to guarantee the implementation of a permanent program for invasive alien species in areas of relevance to the conservation of biodiversity. This fund could be sustained with financial resources provided by environmental compensation and/ or payment for environmental services. ICMBio currently coordinates a management system in which Eucalypus and Pinus plantations, established decades ago for experimental purposes, are being harvested in federal protected areas in exchange for the implementation of invasive alien species control and habitat restoration.

A post-2020 target must follow on the footsteps of actions already in progress and already 
required by existing legislation. For example, the removal of alien species from protected areas in the category of strict protection (unidades de conservação de proteção integral, in Portuguese) is already required (Federal Law 9985/2000). However, as we have shown here, few managers and areas have the required technical knowledge, infrastructure and human resources to fulfill that requirement. Thus, instead of "making plans," a more realistic and objective target would be to provide managers, researchers and stakeholders the necessary skills and means to implement effective management plans to prevent biological invasions and manage important areas for plant diversity that are invaded.

A post-2020 target should also include a way to prioritize areas for restoration from biological invasions, because this is a phenomenon in which timing is key for the success of management actions. The challenge is to identify species that pose significant threats to biodiversity, to determine the nature of the response, and then concert actions to alleviate problems on-the-ground. Management plans should specify the appropriate techniques to prevent, eradicate or control invasive alien species so that ecosystems can be effectively conserved. The need to set priorities in terms of species and areas is covered in the National Strategy and is widely acknowledged by technical staff in governmental agencies and by researchers. In addition, Target 10 suggests that priorities should be set at the national level, but actions must also be coordinated internationally. Successful prevention requires increased efforts in control and regulatory frameworks for invasive plants and pathogens due to international trade and international agreements.

Supplementary data: Occurrence of invasive non-native species in federal protected areas based on management plans and on a questionnaire sent to managers are freely available on the following link: $<$ https://figshare.com/s/e935c7901996848da105> (DOI: 10.6084/m9.figshare.5975425). The data of the questionnaires were already published by Sampaio \& Schmidt 2013. The questionnaire sent to managers of 313 federal protected areas in Brazil and 13 ICMBio Research Centers is also available on the same link.

\section{References}

Aslan CE, Zavaleta ES, Tershy B \& Croll D (2013) Mutualism disruption threatens global plant biodiversity: A systematic review. PLOS ONE 8: e66993.
Bellard C, Cassey P \& Blackburn TM (2016) Alien species as a driver of recent extinctions. Biology Letters 12: 20150623.

Blackburn TM, Cassey P, Duncan RP, Evans KL \& Gaston KJ (2004) Avian extinction and mammalian introductions on oceanic islands. Science 305: 1955-1958.

CDB - Convention on Biological Diversity (2006) Global Biodiversity Outlook 2. Secretariat of the Convention on Biological Diversity, Montreal. $81+$ vii p.

Dawson W, Moser D, van Kleunen M, Kreft H, Pergl $\mathrm{J}$, Pyšek P, Weigelt $\mathrm{P}$, Winter M, Lenzner B, Blackburn TM, Dyer EE, Cassey P, Scrivens SL, Economo EP, Guénard B, Capinha C, Seebens H, García-Díaz P, Nentwig W, García-Berthou E, Casal C, Mandrak NE, Fuller P, Meyer C \& Essl F (2017) Global hotspots and correlates of alien species richness across taxonomic groups. Nature Ecology and Evolution 1: 0186.

Doherty TS,Glen AS, Nimmo DG, Ritchie EG \& Dickman CR (2016) Invasive predators and global biodiversity loss. Proceedings of the National Academy of Sciences of the USA 113: 1126111265.

Forzza RC, Carvalho Jr. A, Andrade ACS, Franco L, Estevão LA, Fonseca-Cruel VS, Coelho MAN, Tamaio N \& Zappi D (2016) Coleções biológicas do Jardim Botânico do Rio de Janeiro à luz das metas da GSPC/CDB: onde estaremos em 2020? Museologia \& Interdisciplinariedade 5: 135-159.

Foxcroft LC, Pyšek P, Richardson DM, Pergl J \& Hulme PE (2014) The bottom line: impacts of alien plant invasions in protected areas. In: Foxcroft LC, Pyšek P, Richardson DM \& Genovesi P (eds.) Plant invasions in protected areas: patterns, problems and challenges. Springer, Dordrecht. Pp. 19-42.

Fukami T, Wardle DA, Bellingham PJ, Mulder CPH, Towns DR, Yeates GW, Bonner KI, Durrett MS, Gran-Hoffman MN \& Williamson WM (2006) Above- and below-ground impacts of introduced predators in seabird-dominated island ecosystems. Ecology Letters 9: 1299-1307.

Gallardo B, Aldridge DC, González-Moreno P, Pergl J, Pizarro M, Pyšek P, Thuiller W, Yesson C \& Vilà M (2017) Protected areas offer refuge for from invasive species spreading under climate change. Global Change Biology 23: 5331-5343.

GBNNSS - Great Britain Non-native species Secretariat (2015) The Invasive Non-Native Species Framework Strategy for Great Britain. Available at $<$ http://www.nonnativespecies.org//index. cfm?sectionid=55>. Access on 10 December 2017.

Gilbert B \& Levine JM (2013) Plant invasions and extinction debts. Proceedings of the National Academy of Sciences of the USA 110: 1744-1749 
Guimarães TCS \& Schmidt IB (2017) A systematization of information on Brazilian federal protected areas with management actions for animal invasive alien species. Perspectives in Ecology and Conservation 15: 136-140.

ICMBio - Instituto Chico Mendes para a Coservação da Biodiversidade (2017) Available at <http:// www.icmbio.gov.br/portal/faunabrasileira/planosde-acao-nacional>. Access on 12 December 2017.

IUCN - International Union for Conservation of Nature (2011) IUCN Plant Conservation subcommittee factsheet. Available at $<$ http://cmsdata.iucn.org/ downloads/guide_gspc__english.pdf $>$. Access on 11 December 2017.

Latini AO, Resende DC, Pombo VB \& Coradin L (orgs.) (2016) Espécies exóticas invasoras de águas continentais no Brasil. Série Biodiversidade 39. MMA, Brasília. 791p.

Laurance WF, Sayer J \& Cassman KG (2014) Agricultural expansion and its impacts on tropical nature. Trends in Ecology and Evolution 29: 107116.

Li Y \& Norland M (2001) The role of soil fertility in invasion of Brazilian pepper (Schinus terebinthifolius) in Everglades National Park, Florida. Soil Science 166: 400-405.

Lopes RM, Coradin L, Pombo VB \& Cunha RD (ed.) (2009) Informe sobre as espécies exóticas invasoras marinhas no Brasil. Série Biodiversidade 33. MMA, Brasília. 440p.

Loope LL, Meyer J-Y \& Hughes RF (2014) Plant invasions in protected areas of tropical Pacific Islands, with special reference to Hawaii. In: Foxcroft LC, Pyšek P, Richardson DM \& Genovesi $\mathrm{P}$ (eds.) Plant invasions in protected areas: patterns, problems and challenges. Springer, Dordrecht. Pp. 313-348

Millennium Ecosystem Assessment (2005) Ecosystems and human well-being: biodiversity synthesis. World Resources Institute, Washington, DC. 100p.

Nogueira EM, Yanai AM, Vasconcelos SS, Alencastro Graça PML \& Fearnside PM (2017) Carbon stocks and losses to deforestation in protected areas in Brazilian Amazonia. Regional Environmental Change: doi 10.1007/s10113-017-1198-1.

Olden JD (2006) Biotic homogenization: a new research agenda for conservation biogeography. Journal of Biogeography 33: 2027-2039.

Pougy N, Verdi M, Fernandez E, Martins M, Loyola R \& Martinelli G (2017) Plano de ação nacional para a conservação da flora endêmica ameaçada de extinção do estado do Rio de Janeiro. Instituto de Pesquisas Jardim Botânico do Rio de Janeiro, Rio de Janeiro. 80p.

Pyšek P, Jarošík V, Hulme PE, Pergl J, Hejda M, Schaffner U \& Vilà M (2012) A global assessment of invasive plant impacts on resident species, communities and ecosystems: the interaction of impact measures, invading species' traits and environment. Global Change Biology 18: 1725-1737.

Reinert BL \& Bornschein MR (2008) Stymphalornis acutirostris. In: Machado ABM, Drumond GM \& Paglia AP (orgs.) Livro vermelho da fauna brasileira ameaçada de extinção. Série Biodiversidade 19. MMA, Brasília. 75p.

Rosenblad KC \& Sax DF (2016) A new framework for investigating biotic homogenization and exploring future trajectories: oceanic island plant and bird assemblages as a case study. Ecography: doi 10.1111/ecog.02652.

Sampaio AB \& Schmidt IB (2013) Espécies Exóticas Invasoras em Unidades de Conservação Federais do Brasil. Biodiversidade Brasileira 3: 32-49.

SANBI - South African National Biodiversity Institute (2008) Available at <http://www.sanbi.org/ biodiversity-science/state-biodiversity/biodiversitymonitoring-assessment/invasive-aliens-early-det $>$. Access on 10 December 2017.

Sharrock S, Oldfield S \& Wilson O (2014) Plant Conservation Report 2014: a review of progress in implementation of the Global Strategy for Plant Conservation 2011-2020. Technical Series No. 81. Secretariat of the Convention on Biological Diversity, Montréal, Canada and Botanic Gardens Conservation International, Richmond. 56 p.

Simberloff D, Martin J-L, Genovesi P, Maris V, Wardle DA, Aronson J, Courchamp F, Galil B, GarcíaBerthou E, Pascal M, Pyšek P, Sousa R, Tabacchi E \& Vilà M (2012) Impacts of biological invasions: what's what and the way forward. Trends in Ecology and Evolution 28: 58-66.

South Africa's Strategy for Plant Conservation (2015) Available at $<$ https://www.cbd.int/doc/world/za/zanbsap-oth-en.pdf $>$. Access on 10 December 2017.

Spatz DR, Zilliacus KM, Holmes ND, Butchart SHM, Genovesi P, Ceballos G, Tershy BR \& Croll DA (2017) Globally threatened vertebrates on islands with invasive species. Science Advances 3: e1603080.

Strassburg BB, Brooks T, Feltran-Barbieri R, Iribarrem A, Crouzeilles R, Loyola R, Latawiec AE, Oliveira Filho FJB, Scaramuzza CAM, Scarano FR, SoaresFilho B \& Balmford A (2017) Moment of truth for the Cerrado hotspot. Nature Ecology \& Evolution 1: 0099.

van Kleunen M, Dawson W, Schlaepfer D, Jeschke JM \& Fischer M (2010) Are invaders different? A conceptual framework of comparative approaches for assessing determinants of invasiveness. Ecology Letters 13: 947-958.

van Kleunen M, Dawson W, Essl F, Pergl J, Winter M, Weber E, Kreft H, Weigelt P, Kartesz J, Nishino M, Antonova LA, Barcelona JF, Cabezas FJ, Cardenas D, Cardenas-Toro J, Castano N, Chacon 
E, Chatelain C, Ebel AL, Figueiredo E, Fuentes N, Groom QJ, Henderson L, Inderjit, Kupriyanov A, Masciadri S, Meerman J, Morozova O, Moser D, Nickrent DL, Patzelt A, Pelser PB, Baptiste MP, Poopath M, Schulze M, Seebens H, Shu WS, Thomas J, Velayos M, Wieringa JJ \& Pyšek P (2015) Global exchange and accumulation of non-native plants. Nature 525: 100-103.

Vilà M, Espinar JL, Hejda M, Hulme PE, Jarošík V, Maron JL, Pergl J, Schaffner U, Sun Y \& Pyšek P (2011) Ecological impacts of invasive alien plants: a meta-analysis of their effects on species; communities and ecosystems. Ecology Letters 14: 702-708.

Vitousek PM, Mooney HA, Lubchenco J \& Melillo JM (1997) Human domination of Earth's ecosystems. Science 277: 494-499.
Wardle DA, Bardgett RD, Callaway RM \& Van der Putten WH (2011) Terrestrial ecosystem responses to species gains and losses. Science 332: 1273-1277.

Zenni RD, Dechoum MS \& Ziller SR (2016) Dez anos do informe brasileiro sobre espécies exóticas invasoras: avanços; lacunas e direções futuras. Biotemas 29: 133-153.

Ziller SR, Reaser JK, Neville LE \& Brand K (2005) Prevenção e manejo de espécies exóticas invasoras: promovendo a cooperação na América do Sul. Programa Global de Espécies Invasoras, Cape Town. 95p.

Ziller SR \& Dechoum MS (2013) Plantas e vertebrados exóticos invasores em unidades de conservação no Brasil. Biodiversidade Brasileira 3: 4-31. 